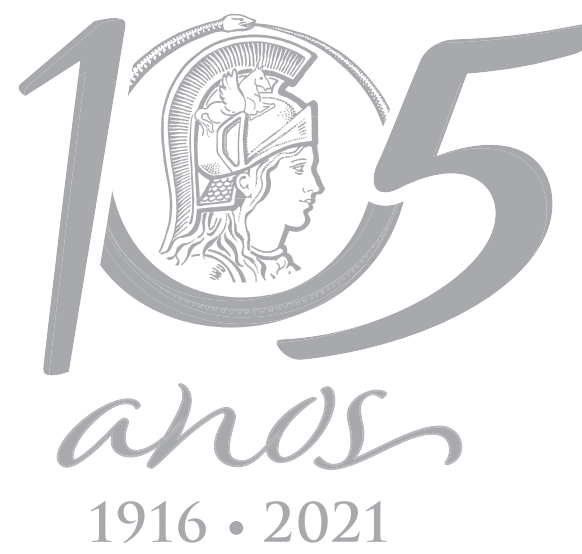

\title{
ECOSYSTEMS
}

\section{Is it possible to use behavior characters for evolutionary reconstruction in marine invertebrates? A methodological approach using Ethokit Logger}

\author{
ISABELA A. DE GODOY, CARLOS C. ALBERTS, CAIO H. NESPOLO, JULIANA DE \\ OLIVEIRA \& SÉRGIO N. STAMPAR
}

\begin{abstract}
The use of behavioral data is quite common in studies of chordate animals and some groups of arthropods; however, these data are usually used in ecological and conservation studies. Their use remains uncommon in phylogenetic reconstructions, especially for non-model groups in behavioral studies. This study aims to evaluate the methodological use of behavioral (feeding process) data with EthoKit Logger in the phylogenetic reconstruction of the Cnidaria, a group in the so-called 'lower' Metazoa. The results indicate considerable cohesion with reconstructions based on molecular data available in previous studies. We therefore suggest that the use of behavioral characters can possible be a useful secondary tool or a proof test for molecular evolutionary reconstructions.
\end{abstract}

Key words: Behavioral data, phylogeny, feeding, marine biology.

\section{INTRODUCTION}

Food provides essential resources for the maintenance and conservation of life. It is an essential resource for invertebrates, and in cnidarians, its importance begins in the larval stage (Schwarz et al. 2002). However, studies of feeding behavior remain inconclusive on its evolution over millions of years or its relationship to the evolutionary history of these groups, though some studies do show that feeding behavior can be related to phylogenetic signal (Martins et al. 2002, Bouetel 2005).

While much is known about the importance of food for invertebrates (Strathmann 1985), the same is not true about the behavioral mechanisms that these animals use to obtain food, especially from an evolutionary perspective. In Cnidaria, most studies on feeding behavior are focused only on the planktonic stages, mainly in jellyfish (subphylum Medusozoa) (Raskoff 2002).

Almost all active benthic predators, including cnidarians, have tentacles, which are important mobile structures with several functions (Shick 1991, Williams et al. 1991). Tentacles are usually found around the mouth opening of these animals, and their primary and best-known function is to capture food (Lira et al. 2012). However, the methods by which these animals use tentacles to catch prey are usually not described or not described in great detail (Shick 1991, Williams et al. 1991).

The motility conferred by the tentacles of polyps is essential to capture prey, which predators confine using a continuous distension and retraction of the tentacles. The foraging habits of these animals differ based on a number 
of factors, including different light intensities, presence of prey, and different water current speeds (Reimer 1971, Levy et al. 2001, Rabelo \& Cascon 2007).

In some species, the function of tentacles extends beyond feeding, and is related to aggressive behaviors against other individuals that invade an individual's space (Willians et al. 1991). However, this behavior is rare in animals as simple as cnidarians. One possible explanation for this is competition for space in the marine environment, an ecological factor that may have eventually favored this type of behavior (Bigger 1980).

\section{Behavior as a phylogenetic character}

Since behavior can undergo major changes in response to the environment in which the animals live, it is often not considered to be a suitable source of phylogenetic characters (Malange et al. 2013). The intrinsic plasticity of behavioral characters, as well as their ephemeral nature, seems to raise doubts that they can fulfill homology criteria (Lorenz 1941, Atz 1970, Baroni Urbani 1989, Bloomberg et al. 2003, Malange et al. 2013). Meanwhile, based on metadata of different kind of behaviors, Bloomberg et al. (2003) found that behavioral traits did have significant phylogenetic signal, though the signal was weaker than that of other character types (e.g., morphological or molecular).

Nonetheless, many studies have successfully used behavior as characters in reconstructing phylogenies (McLennan 1993, Paterson et al. 1995, Alberts 1996, Slikas 1998, Stuart \& Hunter 1998, Bucheli et al. 2002, Noll 2002, DesutterGrandcolas \& Robillard 2003, Robillard et al. 2006, Cap et al. 2008, Malange et al. 2013); however, over the last decade, there has been a reduction in published studies that use this methodology (Price et al. 2011, Malange et al. 2013). The key to successfully using behavior data as phylogenetic characters, which requires homology criteria be satisfied, is to select inherited characters.

Studies have shown that many groups, like Mammalia, Aves, Arachnida, and Insecta, display conservative behaviors (Noll 2002), ranging from life history-related behaviors (Paterson et al. 1995) to courting (Cap et al. 2008), hunting (Vieira \& Japyassú 2002), and grooming (Alberts 1996, Japyassú et al. 2006, Malange et al. 2013). With respect to feeding behavior, since whole feeding apparatus (including morphological and physiological aspects) is inherited and selected, it is reasonable to expect that the behavior is likewise inherited, selected, and, therefore, suitable for use as a phylogenetic character.

While behavior is most commonly described based on its frequency, form, or sequential structure (Japyassú et al. 2006, Bertossa 2011), the latter seems to be the least environmentally sensitive. Alberts (1996), Robillard et al. (2006), Legendre et al. (2008), Japyassú et al. (2006), and Malange et al. (2013) have all successfully used sequences of behavior as phylogenetic characters.

This study aims to test the viability and validity of feeding behavior as a source of information for phylogenetic reconstruction that can be used to support molecular and/or morphological phylogenetic approaches.

\section{MATERIALS AND METHODS}

\section{Materials}

The experimental part of this study was carried out with seven species of the two subphyla of the phylum Cnidaria, the Anthozoaria and Medusozoa (Table I). The experiments and analysis of the videos recorded during the experimental stage were carried out at LEDA (Laboratory of Evolution and Aquatic Diversity of the Faculty of Science and Letters - Assis Campus (FCL UNESP - Assis), Assis, São Paulo, 
Table I. List of species observed in this study.

\begin{tabular}{|c|c|c|c|}
\hline SUBPHYLA & CLASS & SUBCLASS & SPECIES \\
\hline Anthozoaria & & & \\
\hline & Anthozoa & Octocorallia & Carijoa riisei Duchassaing and Michelotti, 1860 \\
\hline & & Hexacorallia & Anthopleura sp. \\
\hline & & & Palythoa variabilis Duerden, 1898 \\
\hline & & Ceriantharia & Ceriantheomorphe brasiliensis (Mello-Leitão, 1919) \\
\hline & & & Isarachnanthus nocturnus Hartog, 1977 \\
\hline Medusozoa & & & \\
\hline & Scyphozoa & Discomedusae & Netrostoma setouchianum Kishinouye, 1902 \\
\hline & Cubozoa & - & Alatina alata Reynaud, 1830 \\
\hline
\end{tabular}

Brazil and at CEBIMar (Marine Biology Center) at the University of São Paulo, São Sebastião, Brazil.

\section{Methods}

\section{Filming in laboratory}

In this step, three specimens of each species (except for the ceriantharian species, $N=1$ ) listed in Table I were kept in aquaria (Anthozoa) or culture plates (Scyphozoa and Cubozoa) at a constant temperature of $20^{\circ} \mathrm{C}$ and fed ad libitum with Artemia sp. Before observational sessions, animals were not fed for 48 hours before the experiment. The animals were then separated, and nauplii of Artemia sp. were offered every 24 hours. The feeding process was filmed for 10 minutes with a slow-motion image capture camera (120 fps) at 14:00h (-3GMT). Observations were repeated ten times (ten subsequent days) for each species, totaling 30 observations (300 minutes) for each species. Throughout the observational phase, we kept medusozoan polyps in artificial seawater to avoid the creation of food via dissolved organic material.

\section{Defining behavioral categories and analysis results}

Cnidarians use tentacles to capture their prey. Observations of tentacular movements are therefore essential for a better understanding of their capture mechanism. To study the mechanisms used, we observed aspects of feeding behavior such as tentacular movements, prey capture, prey manipulation after capture, average time to take the prey to the mouth, and number of tentacles involved in the capturing process. We studied the capture behavior of each species individually and divided them into behavioral categories based on the methodology proposed by Noll (2002) and Madin (1988).

To identify feeding behaviors, we used the EthoKit Logger and EthoSeq programs (Japyassú et al. 2006). EthoKit Logger is an unpublished software (Open Code in the Supplementary Material I) based on EthoLog (Ottoni 2000), which is used to transcribe analogical data of behavior categories into a digital format. It also uses data on the duration and frequency of behavior. We then used the resulting files in EthoSeq to build 
'directed trees,' which were used to create a matrix for phylogenetic reconstructions.

The complete matrix is available in the Supplementary Material II.

\section{Phylogenetic analysis}

Based on the data obtained, we tested whether the feeding behavior displayed by the specimens in this study shows a phylogenetic signal. To do this, we analyzed the data on Winclada (Nixon 2002), where we performed both a parsimonybased method and a heuristic analysis with strict consensus.

\section{RESULTS AND DISCUSSION}

\section{Ethokit logger: a free behavior transcription software}

For the development of EthoKit logger, a software program for animal behavior transcription, we used C\# object-oriented programming language in the Microsoft Visual Studio Community 2017 integrated development environment. This approach offers an easy connection between programming and graphical elements while also allowing the use of the .NET Framework
Class Library. This library includes abstract and concrete classes, advanced interface joint, controls, and components such as data encapsulating structures. This enables the integration of third-party components, string management, data collection, and file access.

The elements required for the software are creation and editing of behavioral categories, primary keys for data entry exclusively via keyboard, a stopwatch, current state event, category section log, category display table, media player (audio/video), and the ability to control the media playback speed.

The output extensions of the software are Only Session File (*.odf), Report File (*.REP), and $\log \left({ }^{*} . \log \right)$, which are compatible with commercially available animal behavior analysis software. The resulting files were used to build 'directed trees' in EthoSeq, which in turn were used to create a matrix for phylogenetic reconstructions. Figure 1 depicts the flowchart of class integration. The complete EthoKit logger software is available as Supplementary Material I.

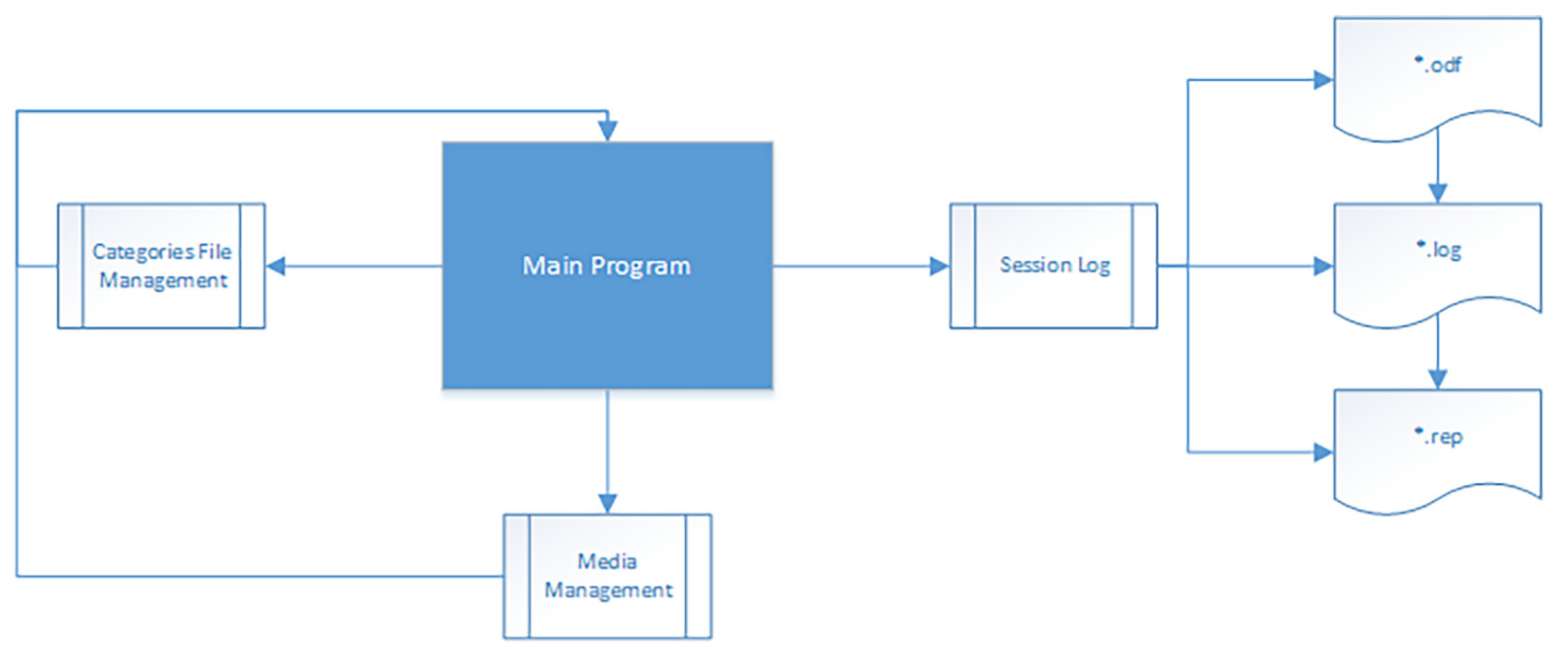

Figure 1. Flowchart of class integration. 


\section{Behavioral categories and analysis results}

We identified the different capture methods adopted by seven cnidarian species, as well as the possible motility patterns observed when cnidarians detect nearby prey (matrix in Supplementary Material II). The tentacles of cnidarians are one of the most important structures for feeding behaviors in this group (Williams et al. 1991), since these structures provide an evident and nematocyst-rich contact surface that enables a broader and more effective prey capture (Raskoff 2002). We analyzed the tentacles of all specimens in this study, and observing that the process of prey capture is based on tentacle movement.

In general, cnidarians' feeding behavior includes capture patterns that involve the injection of a toxin by the cnidae (Fautin 2009). Despite this general pattern, the full process of prey capture can be much more complex and involve a wide variety of strategies and mechanisms. For instance, although uncommon, some species wrap their tentacles around the whole prey and take it toward the mouth, while others capture their prey by directing their mouth and oral cone toward the prey (Ribes et al. 2003, Morandini \& Stampar 2016).

During the first step of the experiment, six of the seven species were observed to use only their tentacles to capture prey and take it toward the mouth. Additionally, except for Alatina alata (Cubozoa), all the species had rapidly mobile tentacles. Despite its slowly moving tentacles, A. alata also uses its tentacles to capture prey. However, instead of moving them, the latter species discharged nematocysts in greater numbers than other species, paralyzing and killing its prey. Both the mouth and oral cone, which are retractable in this species, proceeded to extend and effectively capture the prey, bringing it into the gastrovascular cavity where it was digested. The effectiveness of this behavior relies on the tentacles and the oral region having numerous sensory cells that detect nearby prey (Westfall \& Kinnamon 1984).

\section{Prey capture sequencing}

The data generated by the EthoKit Logger software showed 27 behavioral feeding categories. We also used EthoSeq to generate probable sequences of behavioral categories observed for each species, as follows:

Alatina alata: the prey touches the motionless tentacles of $A$. alata and adheres to them.

Immediately, a nematocyst discharge paralyzes the prey and allows it to be ingested. Sensory cells located in the cnidarian mouth detect the prey adhered to the tentacles, leading to the distension of the oral cone. This process lasts 2-5 minutes. After the distention of the oral cone, the mouth captures the prey and the ingestion process begins within 5 minutes, lasting 2-4 minutes. The distention of the mouth and the oral cone was only observed in this species. Additionally, only one or two prey animals were captured per day.

Anthopleura sp.: its numerous tentacles and well-developed musculature allows this species to contract and expand while seeking food. Shortly after being provided with food by the observer, the elongated and most external tentacles immediately capture 8-9 prey animals and take them to the mouth. Unlike A. alata, prey ingestion in this species occurs immediately after capture. It is also noteworthy that this was the only species that makes use of two tentacles simultaneously to take the prey toward the mouth.

Carijoa riisei: during the feeding process, all tentacles extend; however, we observed that this species can either contract all the tentacles at the same time to capture the prey or contract only one tentacle with the same goal. After 
the prey touches the tentacles, capture begins within 10-20 seconds and the ingestion process lasts around 5 minutes. Carijoa riisei individuals captured and ingested about 17 prey animals per session. This result supports the study of Lira et al. (2012), who suggest that the species is a polyphagous opportunistic species with a passive-suspensive feeding behavior and a preference for small planktonic prey.

Netrostoma setouchianum: the capture behavior begins 1-4 minutes after the prey comes into contact with the tentacles, which are usually distended. We only observed this species capturing three prey animals. The duration of the prey ingestion lasts 1-6 minutes.

Ceriantheomorphe brasiliensis: this species takes up to 30 seconds to initiate the capture process after food becomes available. To capture the prey, it wraps its tentacles around it, leading the prey to the mouth using the marginal tentacles after 3-5 seconds and ingesting it immediately. C. brasiliensis has many tentacles, which allow the species to capture and ingest 53-55 prey animals during the feeding process. Furthermore, it is worth noting that this species was the only one in this study to wrap its tentacles around the prey.

Isarachnanthus nocturnus: the feeding behavior of this species is similar to $C$. brasiliensis, probably because both species belong to the subclass Ceriantharia. After the prey is provided, this species takes 20 seconds to capture it with elongated marginal tentacles. Subsequently, it takes 2 seconds to take the prey to the mouth. However, before this process is carried out, the prey is quickly transferred from the marginal tentacles to the oral tentacles, which then carry the prey to the mouth, where it is ingested. In general, 50 prey animals were captured and ingested during each 10-minute session.

Palythoa variabilis: due to its very distinctive morphology, with tentacles surrounding the oral disc, this species exhibits a very different behavior compared to the other species. The capture process starts around 3 minutes after the prey is provided. In this case, the tentacles do not have a capture function, as they do not show much independent mobility in relation to the oral disk. The oral disk bends to capture the prey. This behavior had been observed in previous studies (e.g., Reimer (1971) (Figure 2)). Once the prey is captured, the pre-oral cavity partially or completely contracts to trap the prey. Finally, the prey is taken to the mouth, and is wholly ingested within 50 seconds. This specimen ingested 3-4 prey animals per session. Moreover, we observed that, except for the prey, light stimuli also cause the pre-oral cavity to partially or completely expand or retract, similar to observations by Rabelo \& Cascon (2007). The feeding behavior aspects of each species are shown in Table II and the numbers of captured and ingested prey during each experimental period are in Table III.

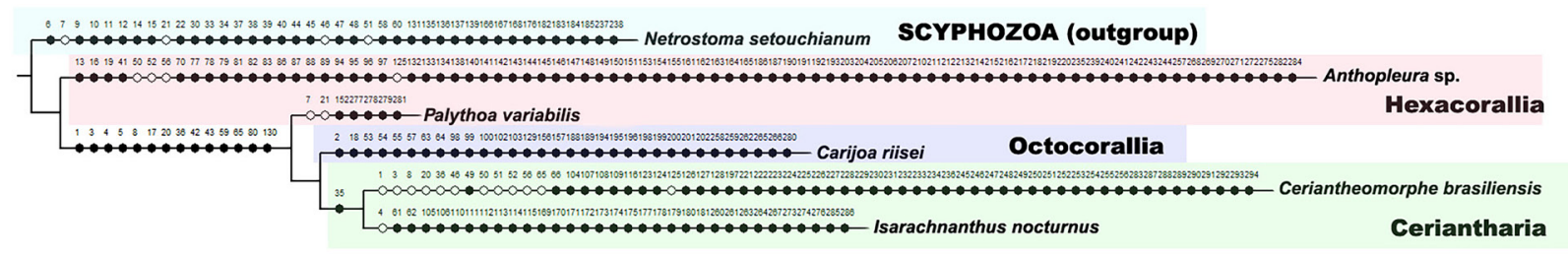

Figure 2. Phylogenetic reconstruction based on characters of feeding behavior. 
Table II. Observation of the feeding behavior to the different groups of cnidarians.

\begin{tabular}{|c|c|c|c|}
\hline & $\begin{array}{c}\text { Average time to start } \\
\text { catching prey }\end{array}$ & $\begin{array}{c}\text { Average time between } \\
\text { catch and ingestion }\end{array}$ & $\begin{array}{c}\text { Mean time of complete } \\
\text { ingestion of prey }\end{array}$ \\
\hline Alatina alata & 5 minutes & 2 to 5 minutes & 2 to 4 minutes \\
\hline Anthopleura sp. & Immediately & 15 to 30 seconds & Immediately \\
\hline Carijoa riisei & 10 to 20 seconds & Up to 5 seconds & Immediately \\
\hline Netrostoma setouchianum & Up to 4 minutes & 1 to 6 minutes & Immutes \\
\hline Ceriantheomorphe brasiliensis & Up to 30 seconds & 3 to 5 seconds & Immediately \\
\hline Isarachnanthus nocturnus & 5 to 20 seconds & Up to 2 seconds & Immediately \\
\hline Palythoa variabilis & Up to 3 minutes & 40 to 50 seconds & Imm \\
\hline
\end{tabular}

Table III. Mean of captured and ingested prey for 10 minutes.

\begin{tabular}{|c|c|c|}
\hline & Average of captured prey & Average of captured and ingested prey \\
\hline Alatina alata & 1 to 2 & Up to 2 \\
\hline Anthopleura sp. & 8 to 9 & 17 \\
\hline Carijoa riisei & 17 & Up to 2 \\
\hline Netrostoma setouchianum & 3 & 53 \\
\hline Ceriantheomorphe brasiliensis & 55 & 50 \\
\hline Isarachnanthus nocturnus & 50 & 3 to 4 \\
\hline
\end{tabular}

\section{Phylogenetic reconstruction based on feeding behavior}

Phylogenetic analysis and phylogenetic reconstructions are concepts and methods based on the theory of biological evolution that allow us to verify phylogenetic affinities between groups. The theory of evolution postulates that modifications in organisms occur infrequently, meaning that evolution is conservative and tends to group organisms according to their similar characteristics. Phylogenetic analyses are therefore based on the assumption that the sharing of modified characteristics between groups indicates affinities between those groups (Futuyma \& Kirkpatrick 2017)

To evaluate if feeding behavior could be used as a tool to obtain phylogenetic reconstructions, we performed a heuristic analysis based on the parsimony method, which minimizes evolutionary events. Our analysis had a strict consensus and was run using Winclada software. Our results generated a tree (Figure 2) that shows the affinities based on feeding behaviors.

Although we did not include Alatina alata to the phylogenetic reconstruction, since it has immobile tentacles, our results 
showed the concise division of the phylum Cnidaria into two subphyla, Anthozoaria and Medusozoa. We designated Netrostoma setouchianum (Scyphozoa) as the outgroup. Our analysis also exhibited the division of the subphylum Anthozoaria into three subclasses: Hexacorallia (not monophyletic), Octocorallia, and Ceriantharia. Our results therefore partially support the current division of the phylum Cnidaria proposed in the literature (e.g., Kayal et al. 2018, Stampar et al. 2019). Although this study did not aim to test the phylogeny, but to present the methodology, the results obtained indicate the possible feasibility of the use of this methodology for phylogenetic reconstructions. It therefore demonstrates that behavioral data can potential be used to establish affinities and recover evolutionary scenarios, contributing to the recovery of phylogenetic data. While the results of this study are promising, further studies with different groups and larger datasets should be conducted to confirm if feeding behavior can be used as a phylogenetic component to other phyla.

\section{Acknowledgments}

This work was partly funded by Fundação de Amparo à Pesquisa do Estado de São Paulo (grant no. 2015/21007-9, 2016/04962-0, 2016/50389-0; 2019/012619 and 2019/03552-0) and Conselho Nacional de Desenvolvimento Científico e Tecnológico (grant no. 304961/2016-7, 404121/2016-0 and 301293/2019-8). We thank Dr. André C. Morandini (IB-USP) for providing access to specimens of Scyphozoa and Cubozoa, to Hellen Ceriello, MSc. for making useful comments to a previous version of the manuscript and to CEBIMar-USP for providing access to infrastructure for experiments.

\section{REFERENCES}

ALBERTS CC. 1996. O comportamento de autolimpeza do gato doméstico (Felis catus) e uma proposta para usálo como caractere filogenético. PhD Thesis, University of São Paulo (CC Alberts, T Sato - 1996 - bdpi.usp.br). (Unpublished).
ATZ JW. 1970. The application of the idea of homology to behavior. In: Aronson L, Tolbach E, Lehrman DS and Rosenblatt JS (Eds), Development and Evolution of Behavior. San Francisco: Freeman, p. 53-74.

BARONI URBANI C. 1989. Phylogeny and behavioural evolution in ants, with a discussion of the role of behaviour in evolutionary processes. Ethol Ecol Evol 1: 137-168.

BERTOSSA RC. 2011. Morphology and behaviour: functional links in development and evolution. Philos Trans R Soc Lond B Biol Sci 366(1574): 2056-2068.

BIGGER CH. 1980. Interspecific and Intraspecific acrorhagial aggressive behavior among sea anemones: A recognition of self and not - self. Biol Bull 159: 117-134.

BLOOMBERG K, WEST D \& IACONO TA. 2003. PICTURE IT: An evaluation of a training program for carers of adults with severe and multiple disabilities. I Intellect Dev Disabil 28(3): 260-282.

BOUETEL V. 2005. Phylogenetic Implications of Skull Structure and Feeding Behavior in Balaenopterids (Cetacea, Mysticeti). J Mammal 86(1): 139-146.

BUCHELI S, LANDRY JF \& WENZEL J. 2002. Larval case architecture and implications of host-plant associations for North American Coleophora (Lepidoptera; Coleophoridae). Cladistics 18(1): 71-93.

CAP H, DELEPORTE P, JOACHIM J \& REBY D. 2008. Male vocal behavior and phylogeny in deer. Cladistics 24(6): 917-931.

DESUTTER-GRANDCOLAS L \& ROBILLARD T. 2003. Phylogeny and the evolution of calling songs in Gryllus (Insecta, Orthoptera, Gryllidae). Zool Scr 32(2): 173-183.

FAUTIN DG. 2009. Structural diversity, systematics, and evolution of cnidae. Toxicon 54(8): 1054-1064.

FUTUYMA DJ \& KIRKPATRICK M. 2017. Evolution, $4^{\text {th }}$ ed., Sunderland. Sinauer, $594 \mathrm{p}$.

JAPYASSÚ HF, ALBERTS CC, IZAR P \& SATO T. 2006. EthoSeq: a tool for phylogenetic analysis and data mining on behavioural sequences. Behav Res Methods 38: 549-556.

KAYAL E, BENTLAGE B, PANKEY MS, OHDERA AH, MEDINA M, PLACHETZKI DC, COLLINS AD \& RYAN JF. 2018. Phylogenomics provides a robust topology of the major cnidarian lineages and insights on the origins of key organismal traits. BMC Evol Biol 18(1): 1-18.

LEGENDRE F, WHITING MF, BORDEREAU C, CANCELLO EM, EVANS TA \& GRANDCOLAS P. 2008. The phylogeny of termites (Dictyoptera: Isoptera) based on mitochondrial and nuclear markers: implications for the evolution of the 
worker and pseudergate castes, and foraging behaviors. Mol Phylogenet Evol 48(2): 615-627.

LEVY O, MIZRAHI L, CHADWICK-FURMAN NE \& ACHITUV Y. 2001. Factors Controlling the Expansion Behavior of Favia favus (Cnidaria: Scleractinia): Effects of Light, Flow and Planktonic Prey. Biol Bull 200: 118-126.

LIRA AKF, GOMES PB, NAUD JP, SANTOS AM \& PÉREZ CD. 2012. Prey selectivity of the octocoral Carijoa riisei at Pernambuco, Brazil. An Acad Bras Cienc 84: 52-80.

LORENZ K. 1941. Vergleichende Bewegungstudien an Anatien. J Ornithology 89: 194-294.

MADIN LP. 1988. Feeding behavior of tentacle predators: in situ observations and a conceptual model. Bull Mar Sci 43(3): 413-429.

MALANGE J, ALBERTS CC, OLIVEIRA ES \& JAPYASSÚ HF. 2013. The evolution of behavioural systems: a study of grooming in rodents. Behaviour 150(11): 1295-1324.

MARTINS M, MARQUES OAV \& SAZIMA I. 2002. Ecological and phylogenetic correlates of feeding habits in Neotropical pitvipers of the genus Bothrops. In: Schuett G, Hoggren M, Douglas M and Greene H (Eds), Biology of the vipers. Eagle Mountain: Eagle Mountain Publishing, p. 307-328.

MCLENNAN DA. 1993. Phylogenetic relationships in the Gasterosteidae: an updated tree based on behavioral characters with a discussion of homoplasy. Copeia 2: 318-326.

MORANDINI AC \& STAMPAR SN. 2016. Cnidaria: Aspectos gerais. In: Fransozo A and Negreiros-Fransozo ML (Eds), Zoologia dos Invertebrados. 1á ed. Rio de Janeiro: Ed. Roca, p. 118-135.

NIXON KC. 2002. WinClada, ver. 1.00.08. Ithaca, Published by the author, available online at http://www.cladistics. com/aboutWinc.htm.

NOLL FB. 2002. Behavioural phylogeny of Corbiculate Apidae (Hymenoptera, Apinae), with special reference to social behaviour. Cladistics 18(2): 137-153.

OTTONI EB. 2000. EthoLog 2.2: A tool for the transcription and timing of behavior observation sessions. Behav Res Methods 32: 446-449.

PATERSON AM, WALLIS GP \& GRAY RD. 1995. Penguins, petrels, and parsimony: Does cladistic analysis of behavior reflect seabird phylogeny?. Evolution 49(5): 974-989.

PRICE JJ, CLAPP MK \& OMLAND KE. 2011. Where have all the trees gone? The declining use of phylogenies in animal behaviour journals. Anim Behav 81(3): 667-670.
RABELO EF \& CASCON HM. 2007. Influence of light on the feeding behaviour of Isaurus tuberculatus Gray, 1828 (Cnidaria: Zoanthidea) under laboratory conditions. Arq Ciên Mar 40(2): 55-58.

RASKOFF KA. 2002. Foraging, prey capture, and gut contents of the mesopelagic narcomedusa Solmissus spp. (Cnidaria: Hydrozoa). Mar Biol 141: 1099-1107.

REIMER AA. 1971. Feeding Behavior in the Hawaiian Zoanthids Palythoa and Zoanthus. Pac Sci 25: 512-520.

RIBES M, COMA R \& ROSSI S. 2003. Natural feeding of the temperate asymbiotic octocoral-gorgonian Leptogorgia sarmentosa (Cnidaria: Octocorallia). Mar Ecol Prog Ser 254: 141-150.

ROBILLARD T, LEGENDRE F, DESUTTER-GRANDCOLAS L \& GRANDCOLAS P. 2006. Phylogenetic analysis and alignment of behavioural sequences by direct optimization. Cladistics 22: 602-633.

SCHWARTZ JA, WEIS VM \& POTTS DC. 2002. Feeding behavior and acquisition of zooxanthellae by planula larvae of the sea anemone Anthopleura elegantissima. Mar Biol 140: 471-478.

SHICK JM. 1991. A Functional Biology of Sea Anemones. Leiden: Springer, 395 p.

SLIKAS B. 1998. Recognizing and testing homology of courtship displays in storks (Aves: Ciconiiformes: Ciconiidae). Evolution 52(3): 884-893.

STAMPAR SN, BROE MB, MACRANDER J, REITZEL AM, BRUGLER MR \& DALY M. 2019. Linear Mitochondrial genome in Anthozoa (Cnidaria): A case study in Ceriantharia. Sci Rep 9(1): 6094.

STRATHMANN RR. 1985. Feeding and nonfeeding larval development and life history evolution in marine invertebrates. Annu Rev Ecol Evol S 16(1): 339-361.

STUART AE \& HUNTER FF. 1998. End-products of behaviour versus behavioural characters: a phylogenetic investigation of pupal cocoon construction and form in some North American black flies (Diptera: Simuliidae). Syst Entomol 23(4): 387-398.

VIERA C \& JAPYASSÚ HF. 2002. Predatory plasticity in Nephilengys cruentata (Araneae: Tetragnathidae): relevance for phylogeny reconstruction. Behaviour 139(4): 529-544.

WESTFALL JA \& KINNAMON CJ. 1984. Perioral synaptic connections and their possible role in the feeding behavior of Hydra. Tissue \& Cell 16(3): 355-365. 
WILLIAMS RB. 1991. Acrorhagi, catch tentacles and sweeper tentacles: a synopsis of aggression of actiniarian and scleractinian Cnidaria. Hydrobiol 216-217: 539-545.

\section{SUPPLEMENTARY MATERIAL}

\section{Supplementary Material I. Application protocol Supplementary Material II. Detailed flowchart of the analysis}

\section{How to cite}

DE GODOY IA, ALBERTS CC, NESPOLO CH, DE OLIVEIRA J \& STAMPAR SN. 2021. Is it possible to use behavior characters for evolutionary reconstruction in marine invertebrates? A methodological approach using Ethokit Logger. An Acad Bras Cienc 93: e20191468. DOI 10.1590/00013765202120191468.

Manuscript received on November 27, 2019;

accepted for publication on August 30, 2020

\section{ISABELA A. DE GODOY ${ }^{1,2}$}

https://orcid.org/0000-0002-1957-2688

\section{CARLOS C. ALBERTS 3}

https://orcid.org/0000-0001-6656-2207

CAIO H. NESPOLO 3

https://orcid.org/0000-0002-8876-3859

JULIANA DE OLIVEIRA ${ }^{3}$

https://orcid.org/0000-0001-8720-0897

\section{SÉRGIO N. STAMPAR ${ }^{1,2}$}

https://orcid.org/0000-0002-9782-1619

"Universidade Estadual Paulista "Júlio de Mesquita Filho" (UNESP), Laboratório de Evolução e Diversidade Aquática (LEDA), Departamento de Ciências Biológicas, FCL/Assis, Av. Dom Antonio, 2100, 19806-900 Assis, SP, Brazil

Universidade Estadual Paulista "Júlio de Mesquita Filho" (UNESP), Instituto de Biociências, Departamento de Zoologia, Distrito de Rubião Júnior, s/n, 18618-970 Botucatu, SP, Brazil

${ }^{3}$ Universidade Estadual Paulista "Júlio de Mesquita Filho" (UNESP), Departamento de Ciências Biológicas, FCL/ Assis, Av. Dom Antonio, 2100, 19806-900 Assis, SP, Brazil

Correspondence to: Sérgio Nascimento Stampar

E-mail:sergio.stampar@unesp.br

\section{Author contributions}

Nespolo and Oliveira contributed to the development and implementation of the EthoKit Logger software, under the guidance of Oliveira and supervision by Alberts. The application of the EthoKit Logger was carried out by Godoy and Stampar, under the supervision of Alberts.

\section{(cc) BY}

